\title{
Lactam Triterpenoids from the Bark of Toona sinensis
}

\author{
Qian-Qian Meng • Xing-Rong Peng • \\ Shuang-Yang Lu $\cdot$ Luo-Sheng Wan • \\ Xia Wang · Jin-Run Dong $\cdot$ Rui Chu • \\ Lin Zhou $\cdot$ Xiao-Nian Li $\cdot$ Ming-Hua Qiu
}

Received: 29 July 2016/Accepted: 22 September 2016/Published online: 18 October 2016

(C) The Author(s) 2016. This article is published with open access at Springerlink.com

\begin{abstract}
Three new limonoid-type triterpenoids, namely toonasins A-C (1-3) with a rare lactam E ring, along with six known compounds (4-9) were isolated from the barks of Toona sinensis. The structures of new compounds were elucidated by interpretation of spectroscopic data, and the relative configuration of compound $\mathbf{1}$ was further characterized by X-ray crystallographic analyses. The isolated compounds were evaluated for their cytotoxic activities against five human tumor cell lines (HL-60, SMMC-7721, A-549, MCF-7 and SW480), and compounds 3 and 5 showed weak cytotoxicities.
\end{abstract}

Keywords Toona sinensis $\cdot$ Limonoids $\cdot$ Lactam triterpenoids $\cdot$ Cytotoxicity

\section{Introduction}

Toona sinensis is a shrub of Meliaceae distributed widely in Asian countries [1]. The leaves of T. sinensis, which contain a distinct flavor, are very popular in vegetarian cuisine and have long been used as a nutritious food in

Qian-Qian Meng and Xing-Rong Peng have contributed equally to this work.

Electronic supplementary material The online version of this article (doi:10.1007/s13659-016-0108-4) contains supplementary material, which is available to authorized users.

Q.-Q. Meng · X.-R. Peng · S.-Y. Lu · L.-S. Wan · X. Wang ·

J.-R. Dong · R. Chu · L. Zhou · X.-N. Li · M.-H. Qiu

State Key Laboratory of Phytochemistry and Plant Resources in

West China, Kunming Institute of Botany, Chinese Academy of

Sciences, Kunming 650201, People's Republic of China

Q.-Q. Meng · S.-Y. Lu $\cdot$ X. Wang $\cdot$ J.-R. Dong $\cdot$ R. Chu ·

M.-H. Qiu

University of the Chinese Academy of Sciences, Beijing 100049,

People's Republic of China

X.-R. Peng · L.-S. Wan · L. Zhou · X.-N. Li · M.-H. Qiu (凹)

Yunnan University of Traditional Chinese Medicine,

Kunming 650500, People's Republic of China

e-mail: mhchiu@mail.kib.ac.cn
China and Malaysia [2]. In folk, almost every part of $T$. sinensis, including seeds, bark, root bark, petioles, and leaves, can be used to treat cold, rheumatic pain, stomach pain, and diarrhea without any irreversible side effects $[3,4]$. Modern pharmacological researches also demonstrated that this plant showed wide spectrum of biological activities, such as antioxidant [5], anti-diabetes [6], antiinflammatory [7], antimicrobial [8], antinociceptive [9] and anti-tumor [10], due to its plentiful chemical constituents (limonoids, flavonoids, phytols, coumarins and norcyteine derivatives) [11-14].

Limonoids were mainly identified from Meliaceae species and possessed fascinating structures [15] and various bioactivities [16-19]. Our previous phytochemical investigation of the Meliaceae species (T. ciliata and Swietenia mahagoni) led to the isolation of structurally diverse limonoids with anti-cancer and anti-bacterial effects $[15,20,21]$. In our continuing search for structurally interesting and biologically important chemical constituents, the bark of the title plant was investigated and three new limonoids, namely toonasins A-C (1-3), along with six known compounds, including one limonoid, photogedunin (4) [22], one tirucallane triterpenoid, bourjotinolone B (5) [23], three pentacyclic triterpenoids, betulinic acid (6) [24], betulin (7) [24], and erythrodiol (8) [25], as 
well as one diterpenoid, gossweilone (9) [26] (Fig. 1) were isolated. Among them, compounds 1-3 had a unique lactam $\mathrm{E}$ ring moiety and were first isolated from this species. The structures of new isolates were elucidated on the basis of the 1D, 2D NMR, and MS spectra. The structure of $\mathbf{1}$ was further confirmed by the X-ray crystallographic analyses. Subsequently, their cytotoxic activities were evaluated by MTT method.

\section{Results and Discussion}

Compound 1 was assigned a molecular formula of $\mathrm{C}_{28} \mathrm{H}_{33} \mathrm{NO}_{8}$ by HRESIMS and 1D NMR spectroscopic data (Table 1), which required 13 degrees of unsaturation. The IR spectrum revealed the presence of $\mathrm{NH}\left(3485 \mathrm{~cm}^{-1}\right)$, carbonyl $\left(1721 \mathrm{~cm}^{-1}\right)$ and amide $\left(1651 \mathrm{~cm}^{-1}\right)$ groups. The ${ }^{1} \mathrm{H}$ NMR spectrum of compound 1 showed five singlet methyls $\left(\delta_{\mathrm{H}} 1.07,1.08,1.18,1.23\right.$ and 1.26), a typical singlet methyl signal at $\delta_{\mathrm{H}} 2.11$ for acetyl, two oxymethines $\left(\delta_{\mathrm{H}} 4.55\right.$, br s, H-7; $\left.\delta_{\mathrm{H}} 3.53, \mathrm{~s}, \mathrm{H}-15\right)$, and three aromatic/olefinic methines $\left(\delta_{\mathrm{H}} 7.12, \mathrm{~d}, J=10.2 \mathrm{~Hz}, \mathrm{H}-1 ; \delta_{\mathrm{H}}\right.$ $\left.5.90, \mathrm{~d}, J=10.2 \mathrm{~Hz}, \mathrm{H}-2 ; \delta_{\mathrm{H}} 6.72, \mathrm{~s}, \mathrm{H}-22\right)$. The ${ }^{13} \mathrm{C}-$ DEPT spectra of $\mathbf{1}$ displayed twenty-eight carbon resonances. Apart from an acetyl group, the remaining signals were assigned as five methyls, three methylenes, an $\alpha, \beta$ unsaturated carbonyl $\left(\delta_{\mathrm{C}} 157.0, \mathrm{C}-1 ; \delta_{\mathrm{C}} 126.2, \mathrm{C}-2 ; \delta_{\mathrm{C}}\right.$ $204.2, \mathrm{C}-3)$, a $\delta$-lactone ring with a 14,15 -epoxy fraction $\left(\delta_{\mathrm{C}} 69.7, \mathrm{C}-14 ; \delta_{\mathrm{C}} 56.8, \mathrm{C}-15 ; \delta_{\mathrm{C}} 166.7, \mathrm{C}-16 ; \delta_{\mathrm{C}} 75.4\right.$,
C-17), and two lactam carbonyls $\left(\delta_{\mathrm{C}} 169.6, \mathrm{C}-21 ; \delta_{\mathrm{C}} 168.8\right.$, C-23), which were further supported by its HSQC, HMBC and ${ }^{1} \mathrm{H}-{ }^{1} \mathrm{H}$ COSY experiments (Fig. 2). Meanwhile, the HMBC correlations of $\mathrm{H}-7$ to the acetyl, C-5, C-6, C-8, C-9, and C-14, and of H-5 and H-6 with C-7, along with the ${ }^{1} \mathrm{H}-{ }^{1} \mathrm{H}$ COSY correlations of $\mathrm{H}-5 / \mathrm{H}-6 / \mathrm{H}-7$ illustrated that the acetoxyl was located at C-7. Above information suggested that 1 was a limonoid-type triterpenoid and resembled photogedunin [22] except that they had a different substituent at $\mathrm{C}-17$.

The presence of a maleimide moiety at $\mathrm{C}-17$ in $\mathbf{1}$ was established by the HMBC correlations of $\mathrm{NH}\left(\delta_{\mathrm{H}} 7.83, \mathrm{~s}\right)$ to C-20, C-21, C-22, and C-23, of H-22 $\left(\delta_{\mathrm{H}} 6.72\right.$, s) to C-17, $\mathrm{C}-20, \mathrm{C}-21$, and C-23 (Fig. 2). The observed ROESY correlations (Fig. 2) of $\mathrm{H}-7 / \mathrm{H}_{3}-19 / \mathrm{H}_{3}-30$, and of $\mathrm{H}-9 / \mathrm{H}_{3}-18$ allowed the assignment of 7-OAc and $\mathrm{H}-9$ as $\alpha$-oriented. To further confirm its skeleton of $\mathbf{1}$, a single crystal was cultivated (Fig. 3). Based on above information, the structure of $\mathbf{1}$ was determined and named as toonasin A (1).

Compound 2 was obtained as a colorless needle with a molecular ion peak at $\mathrm{m} / \mathrm{z} 592.2269[\mathrm{M}+\mathrm{Na}]^{+}$(calcd 569.2261) in the HRESIMS, coincided with the molecular formula of $\mathrm{C}_{30} \mathrm{H}_{35} \mathrm{NO}_{10}$. The IR spectrum exhibited absorption bands for $\mathrm{NH}\left(3435 \mathrm{~cm}^{-1}\right)$, carbonyl $\left(1745 \mathrm{~cm}^{-1}\right)$ and amide $\left(1657 \mathrm{~cm}^{-1}\right)$ groups. Detailed comparison of the 1D NMR data between $\mathbf{1}$ and $\mathbf{2}$ (Table 1) showed that their main difference was an additional acetyl group $\left[\delta_{C} 170.1(\mathrm{~s}), 21.2(\mathrm{q})\right]$ in $\mathbf{2}$ instead of a methylene in 1. Furthermore, the HMBC correlations of H-6 $\left(\delta_{\mathrm{H}} 5.27\right.$,

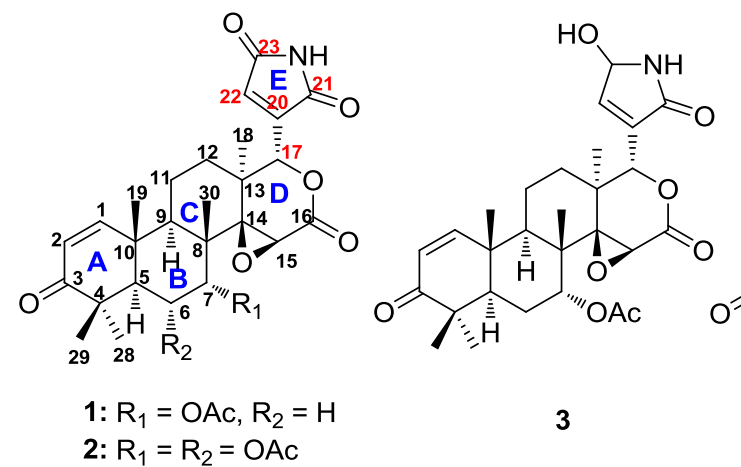

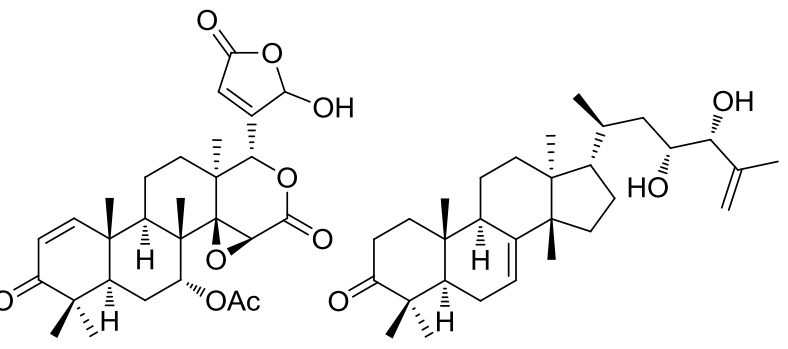

2: $R_{1}=R_{2}=O A C$

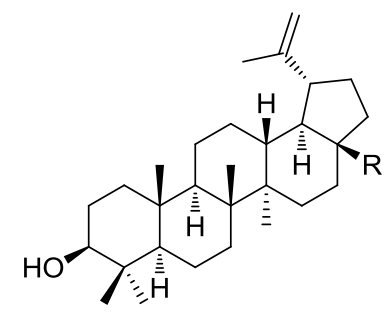

6: $\mathrm{R}=\mathrm{COOH}$

7: $\mathrm{R}=\mathrm{CH}_{2} \mathrm{OH}$

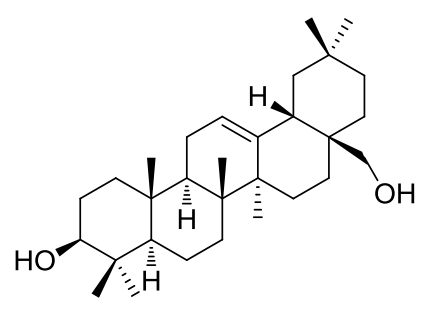

8<smiles>Cc1cc2c(cc1O)[C@@]1(C)CCC(=O)C(C)(C)C1=C(O)C2=O</smiles>

9

Fig. 1 Structures of compounds 1-9 isolated from the bark of Toona sinensis 
Table $1{ }^{1} \mathrm{H}(600 \mathrm{MHz})$ and ${ }^{13} \mathrm{C}$ NMR $(150 \mathrm{MHz})$ data of compounds $\mathbf{1}-\mathbf{3}$ in $\mathrm{CDCl}_{3}$

\begin{tabular}{|c|c|c|c|c|c|c|}
\hline \multirow[t]{2}{*}{ Position } & \multicolumn{2}{|l|}{1} & \multicolumn{2}{|l|}{2} & \multicolumn{2}{|l|}{3} \\
\hline & $\delta_{\mathrm{C}}$ & $\delta_{\mathrm{H}}(J$ in $\mathrm{Hz})$ & $\delta_{\mathrm{C}}$ & $\delta_{\mathrm{H}}(J$ in $\mathrm{Hz})$ & $\delta_{\mathrm{C}}$ & $\delta_{\mathrm{H}}(J$ in $\mathrm{Hz})$ \\
\hline 1 & $157.0, \mathrm{CH}$ & $7.12, \mathrm{~d}(10.2)$ & $155.9, \mathrm{CH}$ & $7.08, \mathrm{~d}(10.1)$ & $157.3, \mathrm{CH}$ & $7.13, \mathrm{~d}(10.2)$ \\
\hline 2 & $126.2, \mathrm{CH}$ & $5.90, \mathrm{~d}(10.2)$ & 126.7, $\mathrm{CH}$ & $5.97, \mathrm{~d}(10.0)$ & $126.1, \mathrm{CH}$ & $5.88, \mathrm{~d}(10.1)$ \\
\hline 3 & $204.2, \mathrm{C}$ & & 204.0, C & & 204.3, C & \\
\hline 4 & $44.2, \mathrm{C}$ & & $44.9, \mathrm{C}$ & & $44.2, \mathrm{C}$ & \\
\hline 5 & $46.1, \mathrm{CH}$ & $2.17, \mathrm{dd}(14.0,2.7)$ & $47.7, \mathrm{CH}$ & $2.52, \mathrm{~d}(12.4)$ & $46.1, \mathrm{CH}$ & $2.17, \mathrm{~d}(12.4)$ \\
\hline 6 & $23.3, \mathrm{CH}_{2}$ & $1.93, \mathrm{~m}$ & $69.5, \mathrm{CH}$ & $5.27, \mathrm{dd}(1.9,12.4)$ & $23.3, \mathrm{CH}_{2}$ & $1.81, \mathrm{t}(14.1) 1.93, \mathrm{~m}$ \\
\hline 7 & $73.3, \mathrm{CH}$ & $4.55, \mathrm{br} \mathrm{s}$ & $72.5, \mathrm{CH}$ & $4.87, \mathrm{~s}$ & $73.3, \mathrm{CH}$ & 4,53, br s \\
\hline 8 & $42.8, \mathrm{C}$ & & 43.0, C & & $42.7, \mathrm{C}$ & \\
\hline 9 & $39.4, \mathrm{CH}$ & $2.45, \mathrm{dd}(12.9,5.8)$ & $38.1, \mathrm{CH}$ & $2.47, \mathrm{dd}(12.9,5.9)$ & $39.6, \mathrm{CH}$ & $2.45, \mathrm{dd}(12.8,6.0)$ \\
\hline 10 & $40.3, \mathrm{C}$ & & $40.5, \mathrm{C}$ & & $40.2, \mathrm{C}$ & \\
\hline \multirow[t]{2}{*}{11} & $15.0, \mathrm{CH}_{2}$ & $2.01, \mathrm{~m}$ & $14.8, \mathrm{CH}_{2}$ & $1.86, \mathrm{~m}$ & 15.0, $\mathrm{CH}_{2}$ & $1.86, \mathrm{~m}$ \\
\hline & & $1.88, \mathrm{~m}$ & & $1.99, \mathrm{~m}$ & & $1.97, \mathrm{~m}$ \\
\hline \multirow[t]{2}{*}{12} & $25.8, \mathrm{CH}_{2}$ & $1.41, \mathrm{~m}$ & $25.5, \mathrm{CH}_{2}$ & $1.44, \mathrm{~m}$ & $25.5, \mathrm{CH}_{2}$ & $1.47, \mathrm{~m}$ \\
\hline & & $2.03, \mathrm{~m}$ & & $2.03, \mathrm{~s}$ & & $2.03, \mathrm{~m}$ \\
\hline 13 & $39.8, \mathrm{C}$ & & $39.7, \mathrm{C}$ & & $39.4, \mathrm{C}$ & \\
\hline 14 & $69.7, \mathrm{C}$ & & 69.6, C & & $69.8, \mathrm{C}$ & \\
\hline 15 & $56.8, \mathrm{CH}$ & $3.53, \mathrm{~s}$ & $55.9, \mathrm{CH}$ & $3.62, \mathrm{~s}$ & $56.9, \mathrm{CH}$ & $3.50, \mathrm{~s}$ \\
\hline 16 & 166.7, C & & 166.7, C & & 167.5, C & \\
\hline 17 & $75.4, \mathrm{CH}$ & $5.68, \mathrm{~s}$ & $75.1, \mathrm{CH}$ & $5.67, \mathrm{~s}$ & 76.0, $\mathrm{CH}$ & $5.57, \mathrm{~s}$ \\
\hline 18 & 17.6, $\mathrm{CH}_{3}$ & $1.26, \mathrm{~s}$ & 17.6, $\mathrm{CH}_{3}$ & $1.25, \mathrm{~s}$ & $18.5, \mathrm{CH}_{3}$ & $1.16, \mathrm{~s}$ \\
\hline 19 & $19.9, \mathrm{CH}_{3}$ & $1.23, \mathrm{~s}$ & $21.5, \mathrm{CH}_{3}$ & $1.22, \mathrm{~s}$ & $19.9, \mathrm{CH}_{3}$ & $1.23, \mathrm{~s}$ \\
\hline 20 & $145.0, \mathrm{C}$ & & $144.8, \mathrm{C}$ & & 136.6, C & \\
\hline 21 & 169.6, C & & $170.1, \mathrm{C}$ & & $170.2, \mathrm{C}$ & \\
\hline 22 & $133.2, \mathrm{CH}$ & $6.72, \mathrm{~s}$ & $133.1, \mathrm{CH}$ & $6.72, \mathrm{~s}$ & $146.3, \mathrm{CH}$ & $7.03, \mathrm{~s}$ \\
\hline 23 & $168.8, \mathrm{C}$ & & $170.0, \mathrm{C}$ & & $78.5, \mathrm{CH}$ & $5.63, \mathrm{~d}(7.02)$ \\
\hline 28 & $27.3, \mathrm{CH}_{3}$ & $1.07, \mathrm{~s}$ & 31.6, $\mathrm{CH}_{3}$ & $1.26, \mathrm{~s}$ & $27.3, \mathrm{CH}_{3}$ & $1.07, \mathrm{~s}$ \\
\hline 29 & $21.3, \mathrm{CH}_{3}$ & $1.08, \mathrm{~s}$ & $20.3, \mathrm{CH}_{3}$ & $1.17, \mathrm{~s}$ & $21.4, \mathrm{CH}_{3}$ & $1.08, \mathrm{~s}$ \\
\hline 30 & $18.5, \mathrm{CH}_{3}$ & $1.18, \mathrm{~s}$ & $18.2, \mathrm{CH}_{3}$ & $1.29, \mathrm{~s}$ & $17.4, \mathrm{CH}_{3}$ & $1.25, \mathrm{~s}$ \\
\hline $\mathrm{NH}$ & & $7.84, \mathrm{~s}$ & & & & $6.35, \mathrm{~s}$ \\
\hline 6- $\underline{\mathrm{COCH}}_{3}$ & & & 170.1, C & & & \\
\hline $6-\mathrm{COCH}_{3}$ & & & $21.2, \mathrm{CH}_{3}$ & $2.03, \mathrm{~s}$ & & \\
\hline $7-\mathrm{COCH}_{3}$ & 170.0, C & & 170.0, C & & 170.1, C & \\
\hline $7-\mathrm{COCH}_{3}$ & $21.2, \mathrm{CH}_{3}$ & $2.11, \mathrm{~s}$ & $21.0, \mathrm{CH}_{3}$ & $2.16, \mathrm{~s}$ & $21.3, \mathrm{CH}_{3}$ & $2.10, \mathrm{~s}$ \\
\hline
\end{tabular}

Assignments are supported with COSY, HSQC, and HMBC experiments

dd, $J=12.4 \mathrm{~Hz}$ ) with the acetyl, C-5, C-7, and C-8, together with ${ }^{1} \mathrm{H}-{ }^{1} \mathrm{H}$ COSY correlations of $\mathrm{H}-5 / \mathrm{H}-6 / \mathrm{H}-7$, indicated that the additional acetoxyl group was connected to C-6. Meanwhile, H-6 and H-7 showed the ROESY correlations with $\mathrm{H}_{3}-18$, suggesting that $\mathrm{H}-6$ and $\mathrm{H}-7$ was $\beta$-oriented. Finally, the structure of $\mathbf{2}$ was determined and named as toonasin $\mathrm{B}(\mathbf{2})$.

Compound 3 displayed a molecule ion peak at $\mathrm{m} / \mathrm{z}$ $536.2358[\mathrm{M}+\mathrm{Na}]^{+}$(calcd for $\mathrm{C}_{28} \mathrm{H}_{35} \mathrm{NO}_{8}, 513.2363$ ) in the positive HRESIMS, consistent with a molecular formula of $\mathrm{C}_{28} \mathrm{H}_{35} \mathrm{NO}_{8}$. The IR absorption bands at 3438,
3328,1637 , and $1711 \mathrm{~cm}^{-1}$ indicated the presence of $\mathrm{NH}$, $\mathrm{OH}, \mathrm{O}=\mathrm{C}-\mathrm{NH}$, and $\mathrm{O}=\mathrm{C}$. The $1 \mathrm{D}$ NMR spectroscopic data (Table 1) of $\mathbf{3}$ were similar with those of $\mathbf{1}$, except for the presence of an oxymethine and the absence of a lactam carbonyl in 3. Comparison of the 1D NMR data between 1 and 3 showed the highfield shift of C-20 $\left(\delta_{\mathrm{C}} 145.0\right.$ for $1 ; \delta_{\mathrm{C}}$ 136.6 for 3$)$ and the downfield shift of C-21 $\left(\delta_{\mathrm{C}} 169.6\right.$ for 1; $\delta_{\mathrm{C}} 170.2$ for 3$)$ and C-22 $\left(\delta_{\mathrm{C}} 133.2\right.$ for $1 ; \delta_{\mathrm{C}} 146.3$ for 3$)$, suggesting that the carbonyl at $\mathrm{C}-23$ in $\mathbf{1}$ could be replaced by the oxymethine $\left(\delta_{\mathrm{C}} 78.5\right)$ in 3 . This deduction was further confirmed by the HMBC correlations of $\mathrm{NH}\left(\delta_{\mathrm{H}}\right.$ 

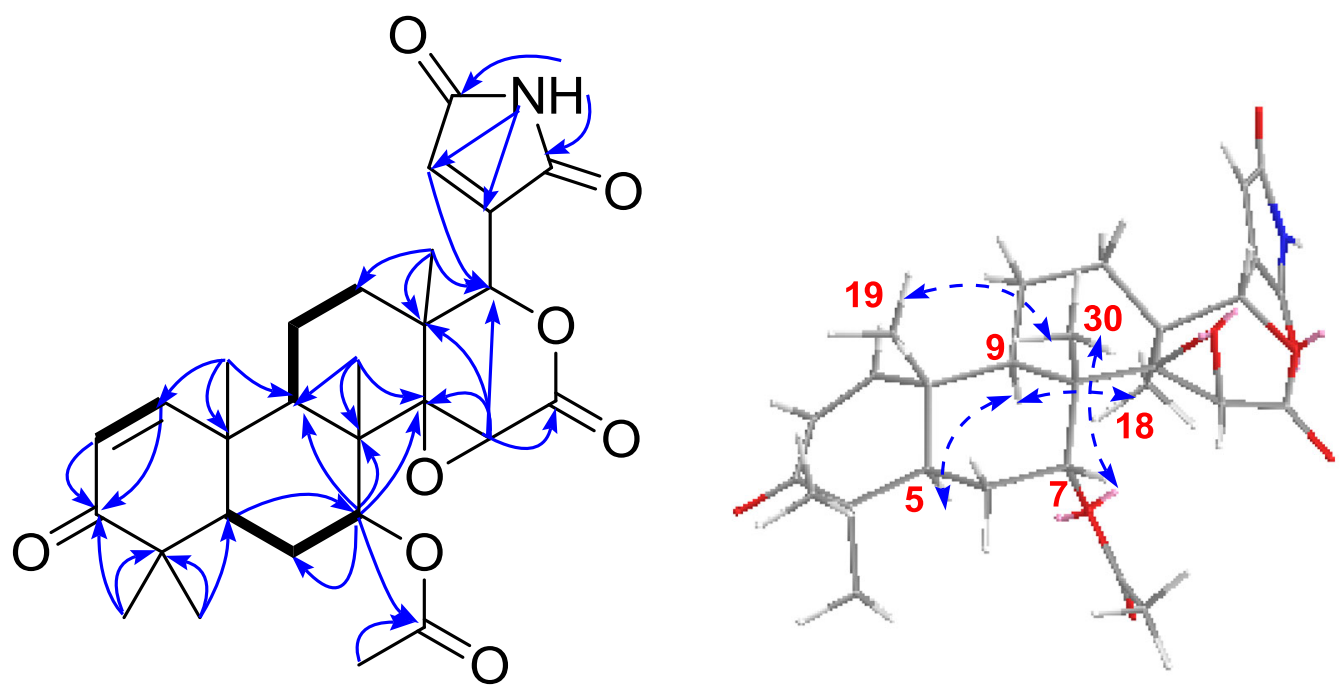

Fig. 2 Key HMBC $(\mathrm{H} \rightarrow \mathrm{C}),{ }^{1} \mathrm{H}^{-1} \mathrm{H} \operatorname{COSY}(-)$ and ROESY $(\sim)$ correlations of $\mathbf{1}$

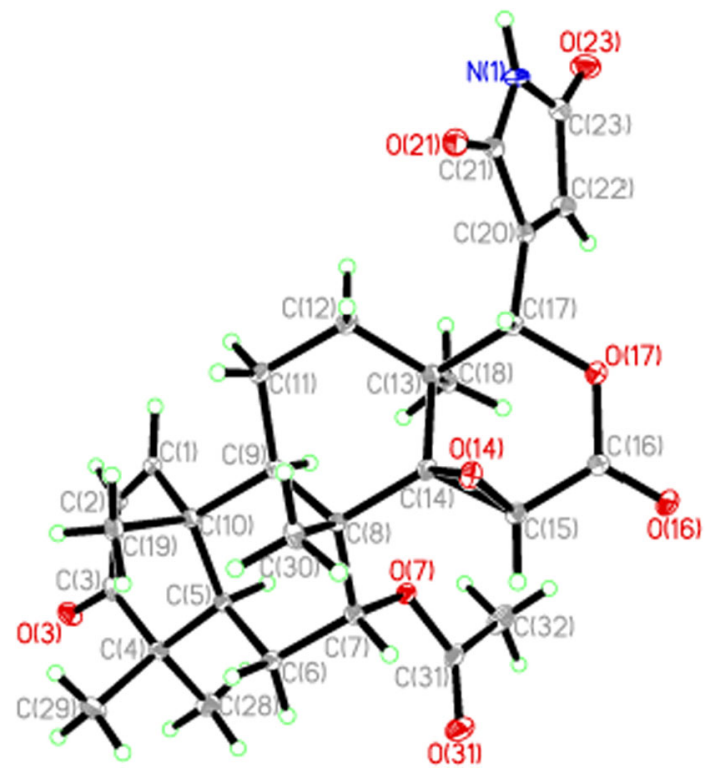

Fig. 3 X-ray structure of 1

6.35, s) with C-20, C-21, C-22, and C-23, of H-23 with $\mathrm{C}-20, \mathrm{C}-21, \mathrm{C}-22$, and $\mathrm{C}-17$, together with the ${ }^{1} \mathrm{H}-{ }^{1} \mathrm{H}$ COSY correlations of NH/H-23/H-22 (Fig. 4). Hence, the structure of $\mathbf{3}$ was established and named as toonasin C (3).

Compounds 3, 4, 5, 7 and 9 were evaluated for their cytotoxicities against five human tumor cell lines (HL-60,

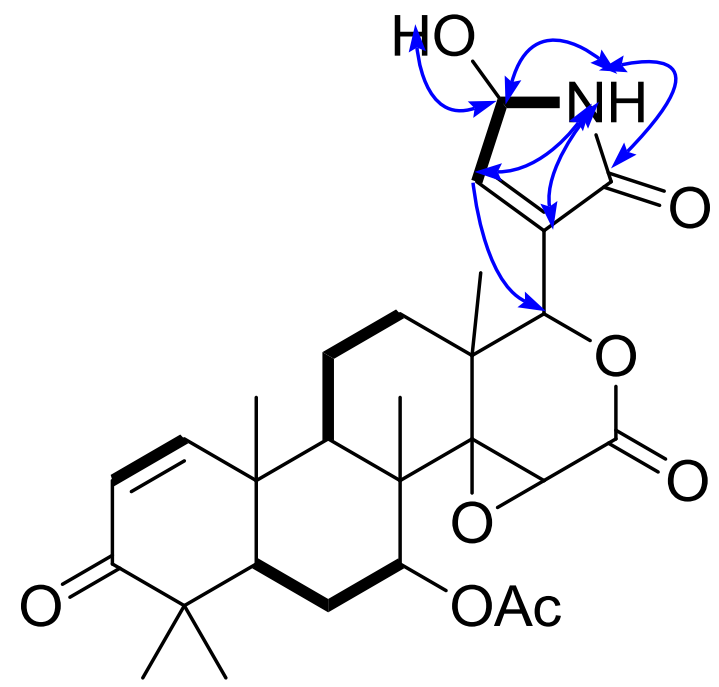

Fig. 4 The selected HMBC $(\mathrm{H} \rightarrow \mathrm{C})$, and ${ }^{1} \mathrm{H}-{ }^{1} \mathrm{H}$ COSY $(-)$ correlations of compound $\mathbf{3}$

SMMC-7721, A-549, MCF-7 and SW480). The results (Table 2) showed that toonasin C (3) and bourjotinolone B (5) have weak inhibition activities against above cell lines with $\mathrm{IC}_{50}$ values of $12.00-25.00 \mu \mathrm{M}$.

To the best our knowledge, the spire leaves of $T$. sinensis were used for a long time as health food and traditional medicine to treat rheumatoid arthritis, cevicitis, ruethritis, gastric ulcers, enteritis, and cancer [1]. However,

Table 2 Cytotoxicity of compounds $\mathbf{3}$ and $\mathbf{5}\left(\mathrm{IC}_{50}: \mu \mathrm{M}\right)$

\begin{tabular}{llllll}
\hline Compound & HL-60 & SMMC-7721 & A-549 & MCF-7 & SW480 \\
\hline $\mathbf{3}$ & $18.61 \pm 0.14$ & $19.55 \pm 0.19$ & $15.07 \pm 0.13$ & $17.79 \pm 0.15$ & $12.47 \pm 0.11$ \\
$\mathbf{5}$ & $14.21 \pm 0.12$ & $18.14 \pm 0.14$ & $17.23 \pm 0.14$ & $24.78 \pm 0.22$ & $24.19 \pm 0.22$ \\
Cis-platin (MW300) & $2.03 \pm 0.01$ & $13.54 \pm 0.12$ & $12.56 \pm 0.10$ & $18.65 \pm 0.15$ & $19.70 \pm 0.20$ \\
\hline
\end{tabular}


phytochemical investigation mainly focused on flavonoids and polyphenols [28-30]. Pharmacological studies documented that the different parts of $T$. sinensis, including bark, seed, flower and root barks, also had various bioactivities [3, 4]. Meanwhile, previous research on the stem bark and leaves of this plant resulted in the isolation of a series of limonoids and the part of them exhibited significant cytotoxic potential $[10,31]$. In the present paper, three novel limonoids with a unique lactam $\mathrm{E}$ ring were identified from the bark of $T$. sinensis, and toonasin C (3) showed comparable cytotoxic effect, with the positive control (Cisplatin), which indicated that limonoids from this plant should be paid more attention in order to explore and develop $T$. sinensis in more depth.

\section{Experimental Section}

\subsection{General}

The optical rotations were taken on a JASCO P-1020 polarimeter. UV spectra were record using a Shimadzu UV2401PC spectrophotometres. ${ }^{1} \mathrm{H}$ and ${ }^{13} \mathrm{C}$ NMR spectra were measured on Bruker AV-600 and DRX-500 instruments (Bruker, Zurich, Switzerland) using TMS as internal standard. Chemical shifts $(\delta)$ were expressed in $p p m$ with reference to the TMS resonance. ESIMS and HRTOFESIMS data were recorded on an API QSTAR Pulsar spectrometer. EIMS and HRTOF-EIMS data were acquired on an Waters Auto Spec Premierp 776 spectrometer (America, Waters). Infrared spectra were recorded on a Bruker Tensor-27 instrument by using $\mathrm{KBr}$ pellets. An agilent 1100 series instrument equipped with Agilent ZORBAX SB-C18 column $(5 \mu \mathrm{m}, 4.6 \mathrm{~mm} \times 250 \mathrm{~mm})$ was used for high-performance liquid chromatography (HPLC) analysis. TLC was performed on precoated TLC plates (200-250 $\mu \mathrm{M}$ thickness, F254 Si gel 60, Qingdao Marine Chemical, Inc.) with compounds visualized by spraying the dried plates with $10 \%$ aqueous $\mathrm{H}_{2} \mathrm{SO}_{4}$ followed by heating until dryness. Silica gel (200-300) mesh, Qingdao Marine Chemical, Inc.), Lichroprep RP-18

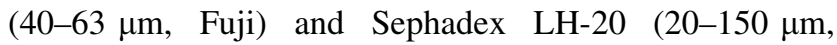
Pharmacia) were used for column chromatography.

The crystal structure of $\mathbf{1}$ was solved by direct method SHELXS-97 (Sheldrich, G. M. University of Gottingen; Gottingen, Germany, 1997) and the full-maxtrix leastsquares deposited in the Cambridge Crystallographic Data Centre. Copies of these data can be obtained free of charge on application to CCDC via the Internet at www.ccdc.cam. ac.uk/conts/retrieving.html (or from the Cambridge Crystallographic Data Center, 12 Union Road, Cambridge CB2 1EZ, U.K.; fax (+44) 1223-336-033; or e-mail: deposit @ccdc.cam.ac.uk).

\subsection{Plant Material}

The barks of $T$. sinensis were purchased from Beijing, China in May 2011, and identified by Prof. Jian Lou. A voucher specimen has been deposited at the State Key Laboratory of Phytochemistry and Plant Resources in West China, Kunming Institute of Botany, Chinese Academy of Sciences.

\subsection{Extraction and Isolation}

The air-dried, powdered the bark of $T$. sinensis $(3.5 \mathrm{~kg})$ were extracted with acetone (98\% acetone/water) for three times (four days at a time) at room temperature. The solution of extracts was concentrated in vacuum to afford dark gummy residues, which was extracted with petroleum ether, chloroform and $n$-buthanol, respectively. The chloroform extract (38 g) was separated on a silica gel chromatography column (CC) with a gradient of Petroleum ether-Acetone $(20: 1,10: 1,8: 1,5: 1,2: 1,1: 2)$ as elution. Then, Petroleum ether-Acetone $(5: 1)$ part was subjected to reverse silica gel $\mathrm{CC}$, eluting with $\mathrm{H}_{2} \mathrm{O}-\mathrm{MeOH}$ (45:55, $35: 65,15: 85)$ to give three fractions $\left(\mathrm{A}_{5}, \mathrm{~B}_{5}, \mathrm{C}_{5}\right)$. Fraction $\mathrm{A}_{5}$ was purified by silica gel $\mathrm{CC}\left(\mathrm{CHCl}_{3}-\mathrm{MeOH}=10: 1\right)$ to gain compound 4 (128 mg). Fraction $\mathrm{C}_{5}$ was subjected to silica gel $\mathrm{CC}$ and eluted with $\mathrm{CHCl}_{3}-\mathrm{MeOH}=10: 1$ to give two subfractions. Moreover, each of subfractions was further purified by semi-preparative HPLC $(100 \% \mathrm{MeOH})$ to yield compounds 5 (3 mg, $6.8 \mathrm{~min}), 6$ (12 $\mathrm{mg}, 7.6 \mathrm{~min})$, 7 (8 $\mathrm{mg}, 8.0 \mathrm{~min})$ and $8(7 \mathrm{mg}, 9.6 \mathrm{~min})$ respectively.

Petroleum ether:Acetone (1:2) part was subjected to reverse silica gel $\mathrm{CC}$, eluting with $\mathrm{H}_{2} \mathrm{O}-\mathrm{MeOH}$ (55:45 to 0:100), to give fractions $A_{1}, B_{1}, C_{1}, D_{1}$, and $E_{1}$. Compound 9 (5 mg) was isolated from fraction $\mathrm{A}_{1}$ by preparative TLC $\left(\mathrm{CHCl}_{3}-\mathrm{MeOH}\right.$, $30: 1)$. Fraction $\mathrm{B}_{1}$ was purified by preparative TLC $\left(\mathrm{CHCl}_{3}-\right.$ $\mathrm{MeOH}, 20: 1)$ to give compound $\mathbf{3}(8 \mathrm{mg})$. Fraction $\mathrm{C}_{1}$ was subjected to silica gel $\mathrm{CC}\left(\mathrm{CHCl}_{3}-\mathrm{MeOH}, 20: 1\right)$ to give a pair of mixture, which was purified by P-TLC $\left(\mathrm{CHCl}_{3}-\mathrm{MeOH}\right.$, $30: 1)$ to yield compounds 1 (30 $\mathrm{mg}$ ) and 2 (3 $\mathrm{mg})$.

\subsubsection{Toonasin A (1)}

Colorless needle; $[\alpha]_{\mathrm{D}}^{23}+76.9^{\circ}\left(c 0.1, \mathrm{CHCl}_{3}\right) ; \mathrm{UV}\left(\mathrm{CHCl}_{3}\right)$ $\lambda_{\max }$ (loge): 239 (2.24), 223 (1.46), 220 (1.46) nm; IR $(\mathrm{KBr}) v_{\max }: 3485,2964,1721,1651,1370,1240,1032$, $826 \mathrm{~cm}^{-1}$; For ${ }^{1} \mathrm{H}$ and ${ }^{13} \mathrm{C}$-DEPT NMR spectroscopic data, see Table 1; HRESIMS: $m / z$ 534.2211 [M $+\mathrm{Na}]^{+}$(calcd for $\left.\mathrm{C}_{28} \mathrm{H}_{33} \mathrm{NO}_{8}, 511.2206\right)$.

\subsubsection{Crystal Data of $\mathbf{1}$}

$\mathrm{C}_{28} \mathrm{H}_{33} \mathrm{NO}_{8}, \mathrm{M}=306.47$; The crystal was colorless and transparent columnar, space group $\mathrm{P} 2{ }_{1} 2{ }_{1} 2_{1} ; a=8.7643$ 
(12) $\AA, \quad b=11.3899 \quad$ (16) $\AA, c=27.007 \quad$ (4) $\AA$, $\alpha=\beta=\gamma=90^{\circ}, V=2695.9$ (6) $\AA^{3}, Z=4, d=1.374$ $\mathrm{g} / \mathrm{cm}^{3}$. A colorless cube of dimensions $0.03 \times 0.16 \times$ $0.40 \mathrm{~mm}^{3}$ was used for X-ray measurement on a Bruker APEX DUO diffraction instrument with monochromatic graphite. Mo $\mathrm{K} \alpha$ radiation. The distance between the crystal and CCD detector is $50 \mathrm{~mm}$. Of the 26448 reflections that were collected, 6661 were unique, and observable points $\left(|\mathrm{F}|^{2} \geq 2 \sigma|\mathrm{F}|^{2}\right) 4978$. The crystal structure of $\mathbf{1}$ reported here is deposited with the Cambridge Crystallographic Data Centre (deposition number: 871944).

\subsubsection{Toonasin B (2)}

Colorless needle; $[\alpha]_{\mathrm{D}}^{23}+85.3^{\circ}\left(c 0.1, \mathrm{CHCl}_{3}\right) ; \mathrm{UV}\left(\mathrm{CHCl}_{3}\right)$ $\lambda_{\max }$ (loge): 239 (2.11), 227 (1.52), 204 (1.38) nm; IR (KBr) $v_{\max }: 3435,2959,2926,1745,1657,1367,1233$, 1030, $931,827 \mathrm{~cm}^{-1}$; HRESIMS: $\mathrm{m} / z \quad 592.2269$ $[\mathrm{M}+\mathrm{Na}]^{+}$(calcd for $\mathrm{C}_{30} \mathrm{H}_{35} \mathrm{NO}_{10}, 569.2261$ ).

\subsubsection{Toonasin C (3)}

Colorless needle; $[\alpha]_{\mathrm{D}}^{23}+24.5^{\circ}\left(c 0.1, \mathrm{CHCl}_{3}\right) ; \mathrm{UV}\left(\mathrm{CHCl}_{3}\right)$ $\lambda_{\max }(\log \varepsilon): 239.4$ (2.01), 208 (1.16), 203 (1.13) nm; IR (KBr) $v_{\max }: 3438,3398,2925,1711,1637,1268,1124$, 1025, $576 \mathrm{~cm}^{-1}$; HRESIMS: $\mathrm{m} / z$ $536.2358[\mathrm{M}+\mathrm{Na}]^{+}$ (calcd for $\mathrm{C}_{28} \mathrm{H}_{35} \mathrm{NO}_{8}, 513.2363$ ).

\subsection{Cytotoxicity Assays}

There are five cancer cell lines including MCF-7, SMMC7721, HL-60, SW480 and A549, which were obtained from Shanghai cell bank in China. Cells were cultured in DMEM medium (Hyclone, USA), supplemented with $10 \%$ fetal bovine serum (Hyclone, USA), in $5 \% \mathrm{CO}_{2}$ at $37{ }^{\circ} \mathrm{C}$. Cytotoxicity was measured by standard MTT assay [27]. After the treatment of samples and positive control, cell viability was detected and a cell growth curve was graphed. The $\mathrm{IC}_{50}$ values were derived from the mean OD values of the triplicate tests versus drug concentration curves and expressed as mean \pm standard deviation.

Acknowledgments This project was financially supported by Major Program of the National Knowledge Innovation of CAS (No. KSCX2YW-G-038), and the Foundation of State Key Laboratory of Phytochemistry and Plant Resources in West China (P2015-ZZ09). Authors also were particularly grateful to Research Group of Prof. Yan Li for bioassay tests.

\section{Compliance with Ethical Standards}

Conflict of Interest The authors declare no conflict of interest.
Open Access This article is distributed under the terms of the Creative Commons Attribution 4.0 International License (http:// creativecommons.org/licenses/by/4.0/), which permits unrestricted use, distribution, and reproduction in any medium, provided you give appropriate credit to the original author(s) and the source, provide a link to the Creative Commons license, and indicate if changes were made.

\section{References}

1. J.M. Edmonds, M. Staniforth, Curtis's Bot. Mag. 15, 186-193 (1998)

2. Y.C. Chen, Y.L. Liang, Y.L. Huang, B.M. Huang, J. Funct. Foods 14, 318-323 (2015)

3. H.L. Chang, H.K. Hsu, J.H. Su, P.H. Wang, Y.F. Chung, Y.C. Chia, L.Y. Tsai, Y.C. Wu, S.S. Yuan, Gynecol. Oncol. 102, 309-314 (2006)

4. Y.Y.J. Wang, Z.E. Xing, Y.Q. Dai, Food Chem. 128, 831-838 (2011)

5. W.J. Yu, C.C. Chang, T.F. Kuo, Food Chem. Toxicol. 50, 1860-1865 (2012)

6. P.H. Wang, M.J. Tsai, C.Y. Hsu, Food Chem. Toxicol. 46, 2554-2560 (2008)

7. C.Y. Hsiang, Y.C. Hseu, Y.C. Chang, Food Chem. 136, 426-434 (2013)

8. J.G. Wu, W. Peng, J. Yi, Y.B. Wu, T.Q. Chen, K.H. Wong, J.Z. Wu, J. Ethnopharmacol. 154, 198-205 (2014)

9. Y.F. Su, Y.C. Yang, H.K. Hsu, S.L. Hwang, K.S. Lee, A.S. Lieu, T.F. Chan, C.L. Lin, BMC Complement Altern. Med. 15, 1 (2015). doi:10.1186/s12906-015-0599-2

10. J. Tang, X. Jian, J. Zhang, W.Y. Liu, N. Xie, L. Chen, F. Feng, W. Qu, Fitoterapia 112, 97-103 (2016)

11. X.J. Dong, Y.F. Zhu, G.H. Bao, F.L. Hu, G.W. Qin, Molecules 18, 2840-2850 (2013)

12. K. Mitsui, M. Maejima, H. Saito, H. Fukaya, Y. Hitotsuyanagi, K. Takeya, Tetrahedron 61, 10569-10582 (2005)

13. I.S. Lee, H.I. Kim, U.J. Youn, Q.C. Chen, J.P. Kim, D.T. Ha, T.M. Ngoc, B.S. Min, S.M. Lee, H.J. Jung, M.K. Na, K.H. Bae, Helv. Chim. Acta 93, 272-276 (2010)

14. J.C. Park, Y.B. Yu, J.H. Lee, J.S. Choi, K.D. Ok, Korea J. Pharmacognosy 27, 219-223 (1996)

15. J.J. Xia, X.Y. Li, S.Z. Zhang, J.Q. Liu, W.M. Zhang, Y.X. Yan, Z.T. Ding, M.H. Qiu, Tetrahedron Lett. 55, 2104-2106 (2014)

16. J.J. Chen, S.S. Huang, C.H. Liao, D.C. Wei, P.J. Sung, T.C. Wang, M.J. Cheng, Food Chem. 120, 379-384 (2010)

17. T.R. Govindachari, G. Suresh, B. Banumathy, S. Masilamani, G. Gopalakrishnan, G.N.K. Kumari, J. Chem. Ecol. 25, 923-933 (1999)

18. S. Falah, T. Suzuki, T. Katayama, Park. J. Biol. Sci. 11, 2007-2012 (2008)

19. R. Fowles, B. Mootoo, R. Ramsewak, A. Khan, A. Ramsubhag, W. Reynolds, M. Nair, Pest Manage. Sci. 66, 1298-1303 (2010)

20. J.Q. Liu, X.R. Peng, W.M. Zhang, L. Shi, X.Y. Li, J.C. Chen, M.H. Qiu, RSC Adv. 3, 4890-4893 (2013)

21. W.M. Zhang, J.Q. Liu, D.Y. Deng, J.J. Xia, Z.R. Zhang, Z.R. Li, M.H. Qiu, Nat. Prod. Bioprospect. 4, 53-57 (2014)

22. C.L. Cespedes, J.S. Calderon, B. King-Diaz, B. Lotina-Hennsen, J. Agric. Food Chem. 46, 2810-2816 (1998)

23. G.J.W. Breen, E. Ritchie, W.T.L. Sidwell, W.C. Taylor, Australian J. Chem. 19, 455-481 (1966)

24. C.P. Reyes, M.J. Nunez, L.A. Jimenez, J. Busserolles, M.J. Alcaraz, I.L. Bazzocchi, Bioorg. Med. Chem. 14, 1573-1579 (2006)

25. X.H. Zheng, L.Z. Zhen, K. Chohachi, D.D. Soejarto, G.A. Cordell, H.H.S. Fong, W. Hodgson, Phytochemistry 27, 233-235 (1988)

26. J.J. Xu, J.T. Fan, G.Z. Zeng, N.H. Tan, Helv. Chim. Acta 94, $842-846$ (2011) 
27. J.J. Chen, H.C. Hung, P.J. Sung, I.S. Chen, W.L. Kuo, Phytochemistry 72, 523-532 (2011)

28. W. Zhang, C. Li, L.J. You, X. Fu, Y.S. Chen, Y.Q. Luo, J. Funct. Foods 10, 427-435 (2014)

29. C.L. Wang, J.X. Shi, Y. Wu, Asian J. Chem. 26, 2557-2560 (2014)
30. K. Akinori, N. Masayuki, E. Mai, A. Morina, H. Masahiro, T. Kaori, K. Mamoru, Bioorg. Med. Chem. Lett. 24, 4286-4290 (2014)

31. J. Hu, Y. Song, X. Mao, Z.J. Wang, Q.J. Zhao, J. Funct. Foods 20, 1-9 (2016) 